\title{
STABILITAS DAN EFEKTIVITAS ANTIOKSIDAN ZAT WARNA ANTOSIANIN TEPUNG KAKAO TANPA FERMENTASI (Theobroma cacao L) SECARA IN VIVO
}

\author{
Antioxidant Stability and Effectiveness of Antosianin Pigmen from Unfermented Cocoa \\ Flour (Theobroma cacao L) by in vivo Method
}

Medan Yumas, Justus E. Loppies, dan Alfrida Lullung S.

Balai Besar Industri Hasil Perkebunan

Jl. Prof. Dr. Abdurahman Basalamah No. 28 Makassar

e-mail: medan.yumas@yahoo.com

\begin{abstract}
Unfermented cocoa flour are known to contain polyphenol compounds called flavonoid which are anthocyanin dyes which can function as antioxidants and active ingredients. The ability of anthocyanin as an antioxidant and active ingredient is a consideration to be applied to a cosmetic or food product. This research aims to determine the antioxidants stability and effectiveness of anthocyanin pigmen of non-fermented cocoa beans by invivo method. The stages of the study consisted of making non-fermented cocoa powder, extraction of anthocyanin compounds by maceration using ethanol and citric acid, and anthocyanin pigmen testing. The results showed that the best anthocyanin pigment from non-fermented cocoa beans with the at $\mathrm{pH}$ 2.89. This anthocyanin pigment has a maximum wave length of $565 \mathrm{~nm}$ with the highest anthocyanin was 0.412 , has a more stable brownish red color, has an antioxidant effect, not toxicity or irritating to the skin, however, toxicity or irritating to the eye.
\end{abstract}

Key words: Unfermented cocoa flour, anthocyanin, extraction, antioxidants, in vivo

Abstrak : Tepung kakao tanpa fermentasi diketahui mengandung senyawa polifenol golongan flavonoid yaitu zat warna antosianin yang dapat berfungsi sebagai antioksidan dan bahan aktif. Kemampuan antosianin sebagai antioksidan dan bahan aktif merupakan pertimbangan untuk diaplikasikan pada suatu produk kosmetik atau pangan. Penelitian ini bertujuan untuk mengetahui stabilitas dan efektivitas antioksidan dari zat warna antosianin tepung kakao tanpa fermentasi secara in vivo. Tahapan penelitian terdiri dari pembuatan tepung kakao tanpa fermentasi, ekstraksi senyawa antosianin secara maserasi menggunakan etanol dan asam sitrat, serta uji zat warna antosianin. Hasil penelitian menunjukkan bahwa zat warna antosianin dari tepung kakao tanpa fermentasi yang terbaik adalah zat warna antosianin dengan pH 2,89. Zat warna antosianin ini memiliki panjang gelombang maksimum $565 \mathrm{~nm}$ dengan serapan antosianin tertinggi sebesar 0,412, memiliki warna merah kecoklatan yang lebih stabil, memiliki efek dan aktivitas antioksidan pada kulit dan mata, tidak bersifat toksik atau iritasi pada kulit, namun bersifat toksik atau iritasi pada mata.

Kata kunci : Tepung kakao tanpa fermentasi, antosianin, ekstraksi, antioksidan, in vivo

\section{PENDAHULUAN}

Warna merupakan salah satu karakteristik yang membuat suatu produk menjadi lebih menarik untuk diminati. Selain itu, penambahan warna dalam suatu produk dapat meningkatkan variasi produk, menambah nilai artistik, dan dapat juga dipakai sebagai sarana identifikasi produk sehingga dapat meningkatkan nilai ekonomi suatu produk. Saat ini sering ditemukan penggunaan pewarna sintetik dalam berbagi macam industri seperti tekstil, makanan, kosmetik dan farmasi. Pewarna sintetik sendiri dapat berdampak buruk terhadap kesehatan dan juga lingkungan.

Upaya mengurangi dampak negatif penggunaan pewarna sintetis dan bahan aktif sintetis dalam produk kosmetik, produk makanan, dan produk farmasi adalah menggunakan bahan pewarna alami dan bahan aktif alami 
atau herbal yang ramah lingkungan. Kembalinya perhatian ke penggunaan pewarna alami dan bahan aktif alami yang dikenal dengan istilah back to nature dianggap sebagai solusi dan sebagai hal yang bermanfaat.

Salah satu zat warna alami yang sering digunakan sebagai pewarna dan bahan aktif alami adalah antosianin. Antosianin merupakan zat warna alami yang berwarna merah, ungu dan biru yang biasa terdapat pada jenis tanaman yang bergantung pada $\mathrm{pH}$ lingkungan termasuk ke dalam komponen bioaktif golongan flavonoid (Torskangerpoll dan Andesen, 2005; Burdulis, et al, 2009; Jensen, et al, 2011). Antosianin dapat menggantikan penggunaan pewarna sintetik rhodamin $B$, carmoisin, dan amaranth sebagai pewarna merah pada produk pangan. Antosianin memiliki kemampuan untuk mengikat radikal bebas dan kemampuan untuk menghambat tahap inisiasi reaksi kimiawi yang menyebabkan karsinogenesis (Arivani, 2010). Antosianin bermanfaat bagi kesehatan manusia. sebagai antioksidan (Takahata et al, 2011; Jiao et al, 2012), antineoplastik, antikarsinogenik, antidiabetes (Sancho dan Pastore, 2012), antiatherogenik, antiviral, dan efek antiinflamsi, menurunkan permeabilitas dan fragilitas kapiler, menghambat agregasi platelet, meningkatkan immunitas, serta mencegah risiko kanker hati (Choi et al., 2010). Antosianin merupakan senyawa flavonoid yang larut dalam air dan aman dikonsumsi sehingga umumnya digunakan sebagai pewarna alami untuk produk makanan maupun minuman serta memiliki kemampuan sebagai antioksidan. Antosianin dapat digunakan sebagai pewarna alami dalam minuman penyegar, Zat warna alami ini berperan terhadap timbulnya warna merah hingga biru pada beberapa bunga, buah dan daun (Wulaningrum, et.al, 2013). Salah satu sifat dari antosianin adalah mengalami perubahan warna dan aktivitas antioksidan yang dipengaruhi oleh $\mathrm{pH}$ dan struktur dari antosianin (Marco et al., 2011). Struktur antosianin berubah pada $\mathrm{pH} 1 ; \mathrm{pH} 4.5$, dan $\mathrm{pH} 7$ (Lee et al, 2005).

Biji kakao tanpa fermentasi merupakan bahan alam yang potensial untuk dijadikan sebagai pewarna alami dan bahan aktif pada produk kosmetik dan pangan. Biji kakao non fermentasi mengandung senyawa polifenol terutama golongan senyawa flavonoid, alkaloid, katekin, steroid/terpenoid dan tannin yang bersifat antioksidan. Kusuma, et al., (2013) juga melaporkan bahwa biji kakao mengandung senyawa polifenol $5-18 \%$, katekin $33-42 \%$, leukosianidin $23-25 \%$, dan antosianin $5 \%$ yang memiliki aktivitas antioksidan dan memiliki potensi sebagai sumber warna alami. Penelitian ini bertujuan untuk mengetahui stabilitas dan efektivitas antioksidan zat warna antosianin biji kakao non fermentasi secara in vivo.

\section{BAHAN DAN METODOLOGI}

\section{Waktu dan Tempat}

Penelitian ini dilakukan pada bulan Februari-November 2017 di Balai Besar Industri Hasil Perkebunan Makassar.

\section{Alat dan Bahan}

Alat yang digunakan pada penelitian ini antara lain : timbangan kapasitas $5 \mathrm{~kg}$, neraca analitik (sartorius), lumpang alu, rotary evaporator merek buchi, blender merek madato, oven merek Venticell 404 dan 222 MMM medcenter GmbH D 82152 Germany, penangas air, $\mathrm{pH}$ meter, cawan penguap (pyrex), mixer, waskom stainless steel, lumpang porcelain, 
corong pisah (pyrex), waterbath merek HH6 RRC, tabung reaksi (pyrex), botol plastik, beaker glass, gelas ukur $1000 \mathrm{ml}$ (pyrex), gelas ukur $10 \mathrm{ml}$ (pyrex), sendok takar, batang pengaduk kaca, toples kaca, masker, sarung tangan, kertas saring, dan wadah pengering.

$$
\text { Sedangkan bahan yang }
$$

digunakan adalah biji kakao tanpa fermentasi yang diperoleh dari Kabupaten Bantaeng, etanol, asam sitrat, asam asetat, natrium hidroksida, aquabides, kertas $\mathrm{pH}$, kertas saring.

\section{Metode Penelitian}

Penelitian ini terdiri atas 3 tahapan yaitu pembuatan tepung kakao tanpa fermentasi, ekstraksi senyawa antosianin, dan uji zat warna alami antosianin.

\section{Tepung kakao tanpa fermentasi}

Buah kakao dibelah dengan menggunakan balok kayu untuk memisahkan biji kakao dari kulit buahnya. Biji kakao yang telah terpisah dari kulit buahnya dicuci bersih dengan air agar terpisah dari pulpnya. Biji kakao dikeringkan di bawah sinar matahari selama 5 hari dan setiap hari dilakukan penjemuran selama 5 jam sampai mencapai kadar air 7\%. Biji kakao kering yang diperoleh, diperkecil ukurannya menggunakan blender hingga membentuk tepung. Tepung kakao tanpa fermentasi digunakan sebagai bahan untuk diekstrak senyawa antosianinya. Proses pembuatan tepung kakao tanpa fermentasi dapat dilihat pada Gambar 1.

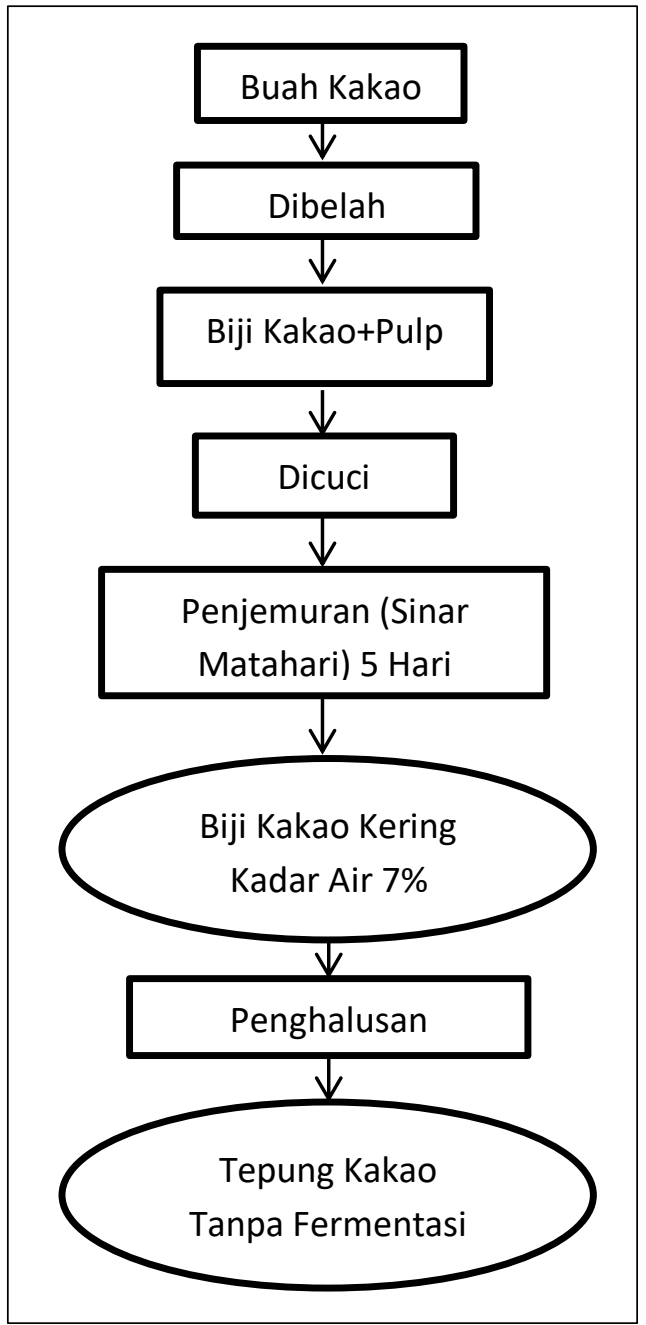

Gambar 1. Proses Pembuatan Tepung Kakao Tanpa Fermentasi

\section{Ekstraksi senyawa antosianin}

Ekstraksi komponen aktif dari tepung kakao tanpa fermentasi dilakukan dengan cara maserasi. Metode ekstraksi ini telah digunakan sebelumnya oleh Wang (2008) yang telah dimodifikasi yaitu perbandingan antara bahan yang diekstrak dengan pelarut etanol yang digunakan $1: 2,5$ liter dalam suasana asam (Yumas, 2017). Sebanyak $1 \mathrm{~kg}$ tepung kakao tanpa fermentasi direndam dengan etanol sebanyak 2,5 liter $(1: 2,5)$ dengan penambahan asam sitrat masing-masing $\mathrm{pH} 2$; $\mathrm{pH} 3$; dan $\mathrm{pH} 4$. Ekstraksi dilakukan secara maserasi dan didiamkan selama 2 hari (48 jam) pada suhu kamar dan masing-masing tiga kali ulangan. Hasil ekstraksi dikumpulkan lalu disaring menggunakan kertas Whatman 
no 41 ke dalam wadah bersih sehingga diperoleh filtrat dan residu. Selanjutnya filtrate diuapkan menggunakan rotary evaporator pada suhu $50^{\circ} \mathrm{C}$ dengan kecepatan putar $60 \mathrm{rpm}$ dan tekanan 100 mBar sampai pelarut tidak menetes lagi atau pelarut habis menguap, dan diperoleh ekstrak kental senyawa antosianin. Proses pembuatan zat warna antosianin ekstrak etanol dengan penambahan asam sitrat dari tepung kakao tanpa fermentasi dapat dilihat pada Gambar 2.

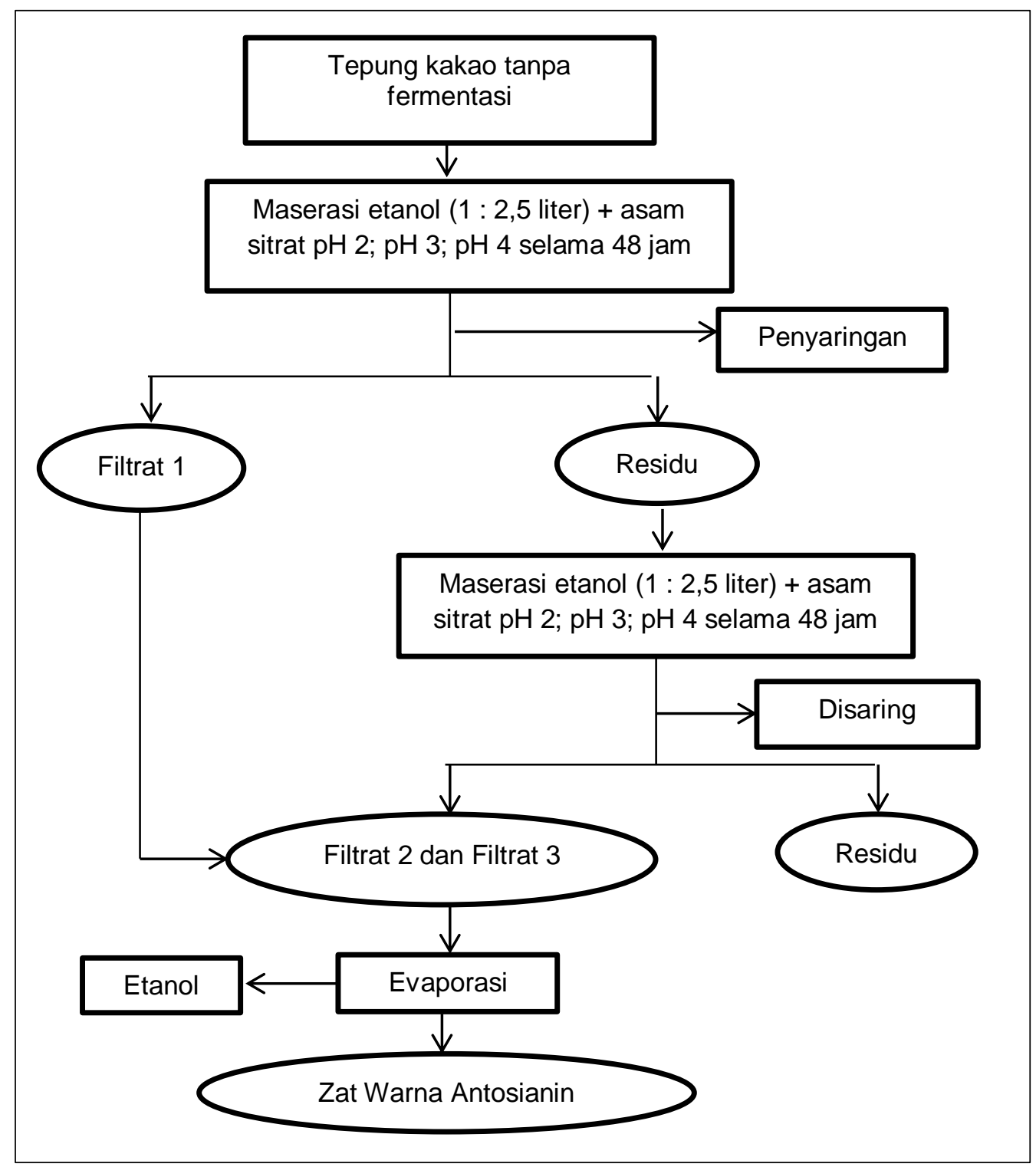

Gambar 2. Proses Pembuatan Zat Warna Antosianin

Analisis Sediaan Zat Warna pada kulit dan mata, Uji iritasi pada kulit Antosianin

Analisis terhadap sediaan zat digunakan sampel uji yang memiliki nilai serapan maksimum terjadi panjang warna antosianin dari ekstrak etanol dengan penambahan asam sitrat dari tepung kakao tanpa fermentasi meliputi gelombang yaitu $565 \mathrm{~nm}$ dan memiliki nilai serapan yang tinggi sebesar 0,412 sampel AS2, serta analisis data hasil uji. 
Uji Stabilitas Zat Warna Antosianin

Penentuan stabilitas zat warna antosianin diawali dengan mencari panjang gelombang maksimum serapan antosianin. Panjang gelombang serapan maksimum antosianin berada sekitar 550-570 nm. Selanjutnya dilakukan penentuan panjang gelombang serapan maksimum masing-masing sampel dengan konsentrasi larutan 1000 ppm. Setelah diperoleh panjang gelombang serapan maksimum, selanjutnya ditentukan stabilitas sampel pada berbagai suhu (Ivo, et al., 2017)

\section{Uji Efek Antioksidan Antosianin}

Uji efek antioksidan antosianin menggunakan metode DPPH, dimana uji dilakukan dalam plat mikro 96 sumur. Pengujian diawali dengan orientasi konsentrasi sampel uji kemudian dilakukan uji sesungguhnya. Setiap ekstrak cair sampel uji diambil $1 \mathrm{ml}$, ditambah $10 \mathrm{ml}$ dengan metanol. Selanjutnya diambil $1 \mathrm{ml}$ larutan tersebut kemudian ditambah $10 \mathrm{ml}$ dengan metanol, dibuat 10.000 ppm. Pembanding berupa vitamin C ditambahkan metanol untuk memperoleh konsentrasi 1000 ppm. DPP ditambahkan metanol untuk memperoleh konsentrasi $60 \mathrm{ppm}$. Sejumlah volume tertentu masing-masing sampel uji ditambah volume sama larutan DPPH 60 ppm, divorteks, kemudian diinkubasi pada suhu kamar di tempat gelap, selama 30 menit. Selanjutnya diukur serapannya pada panjang gelombang serapan maksimum. Sebagai blanko digunakan larutan DPPH yang diperlakukan sama. Sebagai standar digunakan vitamin C. Aktivitas antioksidan dihitung dengan rumus :

Aktivitas $(\%)=(1-($ A sampel/A standar $) x$ 100 , dimana $A$ adalah nilai absorbansi (Ivo, et al., 2017)

\section{Uji Iritasi Pada Kulit}

Uji iritasi pada kulit digunakan sampel uji yang memiliki nilai serapan maksimum terjadi panjang gelombang yaitu $565 \mathrm{~nm}$ dan memiliki nilai serapan yang tinggi sebesar 0,412 sampel AS2. Kelinci diperoleh dari peternakan kelinci di daerah Lembang.Kelinci yang digunakan adalah kelinci albino, galur New Zealand (hybrid), dengan bobot $>2$ kg.Kelinci diaklimatisasi terlebih dahulu selama 3 hari di Laboratorium Pemeliharaan Kelinci sebelum digunakan. Satu hari sebelum percobaan, punggung kelinci dibersihkan dari bulu dengan mencukur.Hanya kelinci dengan kulit sehat dan normal yang digunakan dalam percobaan. Selanjutnya disiapkan dua daerah uji pada punggung kelinci yang telah bersih dari bulu, masing-masing pada sisi kiri dan kanan. Pada masing-masing daerah uji dioleskan sejumlah masing-masing $0,5 \mathrm{ml}$ sampel uji. Selanjutnya daerah uji ditutup dengan kasa hipoalergik, kertas selofan kemudian diperban dengan perban elastis. Kelinci dibiarkan dalam kadang dalam keadaan diperban selama 24 jam. Model uji yang digunakan adalah Uji tempel tertutup (Closed patch test). Tiap sampel diuji pada 3 kelinci. Sesuai panduan pengujian (WHO dan ISO 9003.10) pengamatan dilakukan pada T: 24, 48, dan 72 jam setelah pemberian sampel uji (AS2). Parameter yang diamati adalah eritema-eskar dan udem serta efek-efek lain jika ada, kemudian diberi skor sesuai panduan pengujian. Berdasarkan skor eritema-eskar dan udem selanjutnya dihitung Indeks Iritasi Kutan Primer (IIKP). Sifat iritasi masingmasing sampel pada kulit ditentukan berdasarkan IIKP (Ivo, et al., 2017).

\section{Uji Iritasi Pada Mata}

Kelinci yang digunakan adalah kelinci yang memiliki mata sehat dan 
normal. Selanjutnya sejumlah $0,1 \mathrm{~g}$ sampel uji (AS2) ditempatkan pada kantong konjunctiva salah satu mata kelinci untuk masing-masing kelinci. Mata yang lain dari kelinci yang sama digunakan sebagai kontrol. Sesuai panduan pengujian (WHO dan ISO 10993-10, 1995) pengamatan dilakukan pada $T$ 1, 24, 48, dan 72 jam setelah pemberian sampel. Parameter yang diamati adalah efek pada kornea (opasitas dan luas opasitas), efek pada iris, dan konjunctiva yang meliputi eritema, khemosis, dan lakrimasi serta efek-efek lain jika ada kemudian diberi skor sesuai panduan pengujian (Ivo, et al., 2017)

\section{Analisis Data}

Penelitian ini menggunakan analisis data secara deskriptif. Analisis data secara deskriptif merupakan teknik analisis yang digunakan dalam menganalisis data dengan membuat gambaran data-data yang terkumpul tanpa membuat generalisasi dari hasil penelitian tersebut. Data hasil uji laboratorium pada penelitian ini disajikan dalam bentuk tabel yang selanjutnya dianalisis secara deskriptif.

\section{HASIL DAN PEMBAHASAN}

Stabilitas Warna Antosianin

$\begin{array}{llr}\text { Hasil pengukuran panjang } & \text { prapan } \\ \text { gelombang maksimum } & \text { serapilitas } \\ \text { antosianin untuk penentuan } & \text { stabilan } \\ \text { warna antosianin pada ketiga sampel } & \text { dengan } \\ \text { hasil ekstrak etanol } & \text { deng } \\ \text { penambahan asam sitrat } \mathrm{pH} 2 \text {, pH 3an } \\ \text { pH } 4 \text { dapat dilihat pada Tabel 1. }\end{array}$

Tabel 1. Serapan Sampel Ekstrak Etanol Zat Warna Antosianin Tepung Kakao Tanpa Fermentasi pada Berbagai Panjang Gelombang

\begin{tabular}{cccc}
\hline $\begin{array}{c}\text { Panjang gelombang } \\
(\mathrm{nm})\end{array}$ & \multicolumn{3}{c}{ Serapan Sampel } \\
\cline { 2 - 4 } & $\begin{array}{c}\text { Etanol Asam Sitrat } \\
\mathrm{pH} \text { 2 (AS1) }\end{array}$ & $\begin{array}{c}\text { Etanol Asam Sitrat } \\
\text { pH 3 (AS2) }\end{array}$ & $\begin{array}{c}\text { Etanol Asam Sitrat } \\
\mathrm{pH} 4 \text { (AS3) }\end{array}$ \\
\cline { 2 - 4 } 550 & 0,298 & 0,34 & 0,186 \\
555 & 0,285 & 0,346 & 0,189 \\
560 & 0,258 & 0,318 & 0,183 \\
565 & $\mathbf{0 , 3 5 1}$ & $\mathbf{0 , 4 1 2}$ & $\mathbf{0 , 2 8 4}$ \\
570 & 0,224 & 0,280 & 0,166 \\
575 & 0,206 & 0,260 & 0,159 \\
580 & 0,280 & 0,330 & 0,242 \\
585 & 0,168 & 0,212 & 0,136 \\
590 & 0,149 & 0,186 & 0,120 \\
595 & 0,120 & 0,154 & 0,100 \\
600 & 0,107 & 0,132 & 0,106 \\
\hline
\end{tabular}

Hasil uji derajat keasaman $(\mathrm{pH})$ zat warna antosianin dari tepung kakao tanpa fermentasi untuk masing-masing sampel dapat dilihat pada Tabel 2 .

Tabel 2. Hasil Pengukuran Derajat Keasaman (pH) Sampel Ekstrak Etanol Zat Warna Antosianin Tepung Kakao Tanpa Fermentasi

\begin{tabular}{cccc}
\hline Sampel & \multicolumn{3}{c}{ Serapan Sampel } \\
\cline { 2 - 4 } & AS1 & AS2 & AS3 \\
\hline $\mathrm{pH}$ & 3,34 & 2,89 & 4,30 \\
\hline
\end{tabular}


Tabel 1 menunjukkan bahwa panjang gelombang serapan antosianin berada pada kisaran 550-570 nm dan serapan maksimum terjadi pada panjang gelombang $565 \mathrm{~nm}$. Dari Tabel 1 juga terlihat bahwa semakin bertambah panjang gelombang, semakin berkurang nilai serapan antosianin yang dihasilkan. Nilai serapan antosianin pada sampel AS2 pH 2,89 dan pada sampel AS1 pH 3,34 (Tabel 2) pada dasarnya tidak berbeda nyata atau memiliki kecenderungan warna antosianin yang stabil. Terjadinya kestabilan warna antosianin pada sampel AS2 dan sampel AS1 dikarenakan pada $\mathrm{pH} 2,89$ dan $\mathrm{pH}$ 3,4 (Tabel 2) tersebut antosianin berada dalam bentuk kation flavilium yang merupakan bentuk paling stabil $(\mathrm{pH} 1-3)$. Bila dibandingkan dengan serapan antosianin pada sampel AS3 dengan $\mathrm{pH}$ 4,30 nilai serapan antosianin mengalami penurunan. Hal ini menunjukkan bahwa semakin meningkat nilai $\mathrm{pH}$ maka semakin menurun nilai absorbansinya dan semakin pudar warna merah yang dihasilkan. Nilai serapan antosianin tertinggi diperoleh pada sampel AS2 sebesar 0,412 dan terendah pada sampel AS3. Antosianin pada $\mathrm{pH}$ rendah bersifat asam, menyebabkan elektron lebih sulit untuk terdeprotonasi sehingga antosianin menjadi sangat stabil dan sulit berikatan dengan molekul lain. Selain itu, muatan yang ada pada kation flavilum dapat menghambat terjadinya perpindahan elektron. Hal ini sesuai hasil penelitian yang dialporkan oleh Moulana, et al (2012) bahwa nilai $\mathrm{pH}$ sangat berhubungan dengan kadar intensitas warna dan kadar antosianin dimana perubahan warna disebabkan karena perubahan $\mathrm{pH}$. Nilai $\mathrm{pH}$ tinggi menyebabkan terjadinya perubahan warna antosianinnya yaitu biru $(\mathrm{pH} 8)$, hijau ( $\mathrm{pH} 12)$, dan kuning ( $\mathrm{pH} 13)$ yang menunjukkan tingkat perubahan warna antosianin yang dihasilkan pada proses ekstraksi.

Pada dasarnya, perubahan serapan antosianin yang berakibat pada penurunan nilai absorbansi dan perubahan warna dikarenakan nilai $\mathrm{pH}$ semakin meningkat. Peningkatan $\mathrm{pH}$ (Tabel 2) menunjukkan nilai serapan antosianin semakin menurun sehingga warna antosianin memudar akibat kation flavilium yang berwarna merah mengalami hidrasi menjadi pseudobasa hemiketal karbinol, kuinonoidal dan kalkon yang tidak berwarna. Pada $\mathrm{pH}$ tinggi senyawa ini cepat terhidrolisis menjadi kalkon yang terionisai sempurna. Hal inilah yang menyebabkan antosianin mudah rusak pada kondisi $\mathrm{pH}$ tinggi. Selain itu antosianin juga dapat terdegradasi oleh adanya oksigen dan oksidasi enzimatik, misal polifenol oksidase yang menghasilkan perubahan warna yang signifikan. Namun demikian penurunan absorbansi tersebut tidak merubah pigmen pada hasil ekstraksi. Hal ini sejalan apa yang dikemukan oleh (Reyes dan Cisneros-Zepallos, 2007; Marco et al, 2011) bahwa perubahan warna antosianin akibat terjadinya perubahan struktur antosianin. Sedangkan menurut Suda, et al (2003) menyatakan bahwa $\mathrm{pH}$ 1-2, antioksidan dominan dalam bentuk kation plavilium yang berwarna merah, pada $\mathrm{pH}<6$ berubah menjadi karbinol dan sebagian menjadi kuinonoidal yang berwarna biru, pada $\mathrm{pH}$ 6,5-9 dominan kuinonoidal berwarna biru dan $\mathrm{pH}>9$ kalkon yang berwarna kuning. Kestabilan antosianin dipengaruhi oleh $\mathrm{pH}$, adapun struktur dan perubahan warna pada antosianin karena perbedaan tingkatan $\mathrm{pH}$, dapat dilihat pada gambar 1 . 


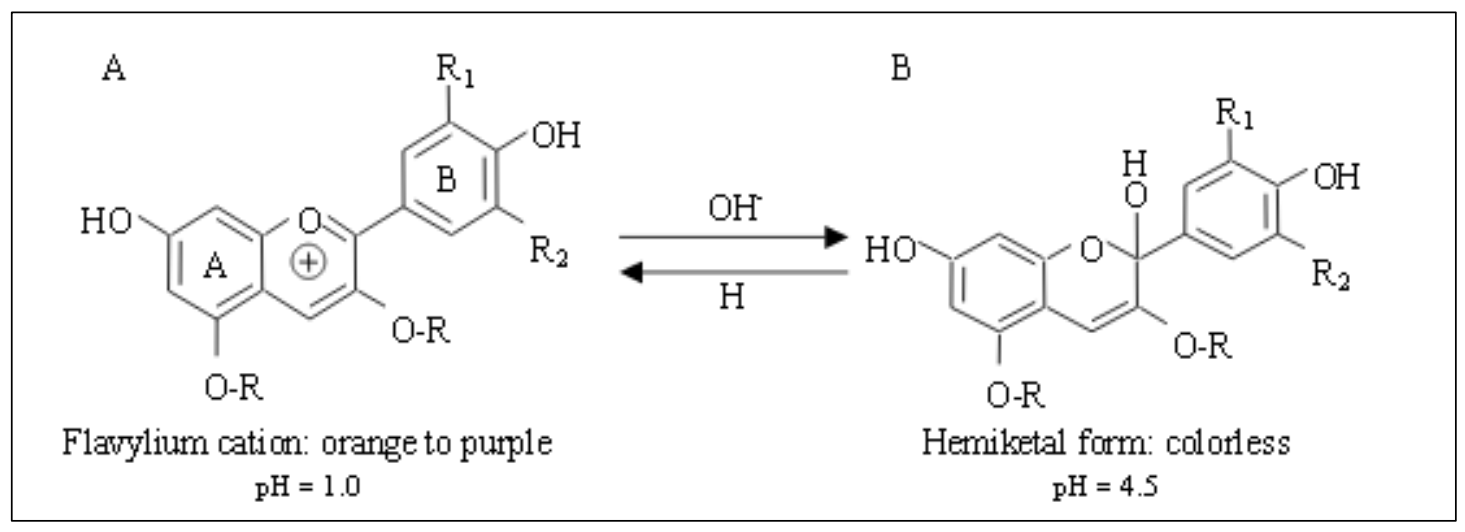

Gambar 3. Struktur antosianin pada pH 1,0 dan pH 4,5 (Wrolstad et al., 2005)

Stabilitas antosianin juga dipengaruhi oleh suhu lingkungan.

Proses pemanasan juga merupakan faktor yang dapat menyebabkan kerusakan antosianin. Hasil pengamatan stabilitas zat warna antosianin terhadap pengaruh suhu antara $40-62^{\circ} \mathrm{C}$ selama 10 menit dapat dilihat pada Tabel 3 di bawah ini.

Tabel 3. Stabilitas Zat Warna Antosianin Ekstrak Etanol Tepung Kakao Tanpa Fermentasi Setelah Disimpan pada Berbagai Suhu.

\begin{tabular}{cccc}
\hline Suhu $\left({ }^{\circ} \mathrm{C}\right)$ & \multicolumn{3}{c}{ Serapan Sampel } \\
\cline { 2 - 4 } & AS1 & AS2 & AS3 \\
\hline Kamar/Ruang & 0,351 & 0,412 & 0,284 \\
40 & 0,097 & 0,240 & 0,041 \\
52 & 0,086 & 0,232 & 0,036 \\
62 & 0,074 & 0,215 & 0,027 \\
\hline
\end{tabular}

Tabel 3 di atas menunjukkan bahwa nilai serapan antosianin atau stabilitas zat warna antosianin mengalami penurunan seiring dengan bertambahnya suhu pemanasan. Ekstrak warna merah yang diperoleh dari tepung kakao tanpa fermentasi menggunakan etanol dengan penambahan asam sitrat bersifat tidak stabil akibat pemanasan. Penurunan nilai serapan absorbansi antosianin terjadi akibat gugus kromofor zat warna atau pigmen yang menyebabkan kerusakan warna. Menurunnya stabilitas warna akibat pengaruh suhu yang tinggi diduga disebabkan terjadinya dekomposisi antosianin dari bentuk aglikon menjadi kalkon (tidak berwarna), bahkan pada temperatur yang tinggi antosianin mengalami degradasi menjadi produk keton. Kerusakan akibat pemanasan dapat terjadi melalui dua tahap, pertama terjadi hidrolisis ikatan glikosidik antosianin sehingga menghasilkan aglikon-aglikon yang tidak stabil, kemudian cincin aglikon terbuka membentuk gugus carbinol dan chalcone. Menurut Hidayah, et al. (2014) menyatakan bahwa suhu dan lama penyinaran menyebabkan terjadinya dekomposisi dan perubahan struktur pigmen sehingga terjadi pemucatan. Sedangkan menurut Sari dan Puspita (2005) menyatakan bahwa proses pemanasan dapat menyebabkan hilangnya warna merah dari antosianin dan meningkatnya warna coklat sebagai hasil dari degradasi dan polimerasi pigmen. Hal ini serupa dengan penelitan Laleh (2006) yang melaporkan hasil yang sama yaitu persentase penurunan antosianin pada ekstrak empat spesies 
buah Berberis ( $B$. khorasanica, $B$. kecepatan oksidasi pada bahan yang integerrima, $B$. orthobotrys, and $B$. mudah teroksidasi. Aktivitas antioksidan vulgaris) semakin meningkat dengan adanya perlakuan suhu yang semakin tinggi. Hasil penelitian ini sejalan dengan penelitian Hidayah, et al (2014) menyatakan bahwa suhu berpengaruh terhadap stabilitas warna, dimana semakin tinggi suhu pemanasan maka absorbansi atau stabilitas warna semakin rendah sehingga warna merah akan berkurang.

\section{Aktivitas Antioksidan Warna Antosianin} yang tinggi menunjukan kemampuan sampel mereduksi radikal bebas yang lebih kuat. Kemampuan menangkap radikal bebas DPPH sampel didasarkan pada kemampuan mereduksi radikal bebas yang ditandai dengan penurunan intensitas warna larutan ungu, karena DPPH menangkap atom hidrogen dari senyawa fenolik sehingga terbentuk senyawa DPPH berwarna kuning yang stabil. (Marliana, 2012). Hasil pengukuran aktivitas antioksidan sampel AS1, sampel AS2, dan sampel AS3 Antioksidan merupakan substansi kimia yang dapat menghambat dengan metode uji DPPH, dapat dilihat pada Tabel 4 di bawah ini.

Tabel 4. Aktivitas antioksidan zat warna antosianin ekstrak etanol tepung kakao tanpa fermentasi pada Berbagai Konsentrasi

\begin{tabular}{lccc}
\hline Konsentrasi $(\mathrm{ppm})$ & \multicolumn{3}{c}{ \% Inhibisi perendaman DPPH } \\
\cline { 2 - 4 } & AS1 & AS2 & AS3 \\
\hline 5000 & 90.05 & 89,93 & 91,55 \\
2500 & 91,39 & 92,21 & 90,94 \\
1250 & 86,21 & 88,97 & 92,14 \\
625 & 71,19 & 76,25 & 85,10 \\
312,5 & 54,51 & 56,63 & 71,36 \\
156,25 & 39,44 & 40,26 & 52,91 \\
78,125 & 28,50 & 31,72 & 39,06 \\
39,0625 & 41,56 & 42,01 & 44,92 \\
\hline
\end{tabular}

Tabel 4 di atas terlihat bahwa aktivititas antioksidan tertinggi untuk masing-masing sampel uji pada kosentrasi 2500 ppm dengan persentase perendaman DPPH diatas 90\%. Aktivitas antioksidan untuk ketiga sampel uji berada pada kisaran 90,94\%-92,21\% dengan aktivitas antioksidan tertinggi diperoleh pada $\mathrm{pH} 2,89$ (Tabel 2) sebesar $92,91 \%$ dengan panjang gelombang $565 \mathrm{~nm}$ dengan serapan antosianin 0,412 (Tabel 1). Hasil tersebut menunjukkan bahwa antosianin dari biji kakao non fermentasi yang diekstrak menggunakan etanol dengan penambahan asam sitrat dengan $\mathrm{pH}$ 2,89 (Tabel 2) memiliki aktivitas antioksidan yang lebih tinggi bila dibandingkan dengan penambahan asam sitrat pada $\mathrm{pH} \mathrm{4,30} \mathrm{(Tabel} \mathrm{2).} \mathrm{Hal}$ ini menunjukkan bahwa semakin asam larutan antosianin semakin tinggi nilai antioksidannya dan berkorelasi positif dengan kandungan polifenol dalam ekstrak karena polifenol memiliki aktivitas sebagai antioksidan. Semakin tinggi kandungan polifenol maka semakin besar aktivitas antioksidannya karena antosianin tersusun dari senyawa polifenol yang memiliki aktivitas penangkap radikal bebas. Sebaliknya semakin meningkat pertambahan nilai $\mathrm{pH}$ maka aktivitas antioksidan akan semakin menurun (Tabel 2). Hal ini 
dkarenakan pada $\mathrm{pH}$ rendah, densitas ion hidrogen meningkat sehingga menekan pelepasan ion hidrogen dari senyawa fenolik. Ion hidrogen ini berfungsi sebagai pendonor untuk menstabilkan radikal. Dengan meningkatnya $\mathrm{pH}$ maka konsentrasi ion hidrogen dalam media menurun sehingga mulai terjadi pelepasan ion hidrogen oleh senyawa antioksidan Senyawa yang bereaksi sebagai penangkap radikal akan mereduksi DPPH membentuk DPPH-H yang tereduksi. Reaksi ini diamati dengan adanya perubahan warna DPPH dari ungu menjadi kuning ketika elektron ganjil dari radikal DPPH telah berpasangan dengan hidrogen dari senyawa penangkap radikal bebas (Molyneux, 2004).

Kecenderungan pola pergerakan prosentase aktivitas penangkapan radikal bebas DPPH dan kekuatan mereduksi ekstrak antosianin dari tepung kakao tanpa fermentasi (Tabel 4) menunjukkan pola pergerakan yang teratur. Dimana pola pergerakan itu terlihat dari sampel uji AS1 meningkat sampai mencapai puncak pada sampel uji AS2, lalu menurun ke sampel uji AS3. Dikaitkan dengan derajat keasaman larutan antosianin (Tabel 2) terdapat pengaruh derajat keasaman terhadap peningkatan prosentase aktivitas penangkapan radikal bebas, dimana semakin asam suatu larutan antosianin maka prosentase aktivitas penangkapan radikal bebas DPPH dan kekuatan mereduksi semakin meningkat (Tabel 2 dan Tabel 4). DPPH merupakan radikal bebas yang memiliki elektron tidak berpasangan dan mempunyai absorbansi maksimum pada panjang gelombang $565 \mathrm{~nm}$. Antioksidan dapat mendonorkan hidrogen atau elektron, sehingga elektron radikal pada DPPH menjadi berpasangan.yang ditandai dengan berubahnya warna DPPH. Kecepatan perubahan warna menunjukkan kekuatan penangkapan radikal bebas dari senyawa antioksidan, ditandai dengan semakin menurunnya absorbansi pada panjang gelombang $565 \mathrm{~nm}$ (Tabel 1).

Aktivitas antioksidan pada tepung kakao tanpa fermentasi dipengaruhi oleh nilai $\mathrm{pH}$. Seiring dengan peningkatan $\mathrm{pH}$ maka aktivitas antioksidan akan semakin menurun (Tabel 4). Hasil penelitian ini sejalan dengan yang dilaporkan oleh Fathinatullabibah, et al (2014) bahwa semakin tinggi nilai $\mathrm{pH}$ maka aktivitas antioksidan semakin menurun. Hal ini dkarenakan pada $\mathrm{pH}$ rendah, densitas ion hidrogen meningkat sehingga menekan pelepasan ion hidrogen dari senyawa fenolik. Ion hidrogen ini berfungsi sebagai pendonor untuk menstabilkan radikal. Demikian juga (Tensiska, 2003) melaporkan bahwa dengan meningkatnya $\mathrm{pH}$ maka konsentrasi ion hidrogen dalam media menurun sehingga mulai terjadi pelepasan ion hidrogen oleh senyawa antioksidan. Biji kakao tanpa fermentasi memiliki kandungan antosianin yang berfungsi sebagai antioksidan yang relatif tinggi sehingga dapat dipertimbangkan sebagai salah satu sumber antioksidan alami.

\section{Efektivitas Zat Warna Antosianin Terhadap Kulit dan Mata}

Hasil uji iritasi zat warna antosianin dari tepung kakao tanpa fermentasi terhadap kulit menggunakan sampel uji AS2 karena sampel ini memiliki warna antosianin yang lebih stabil. Hasil uji zat warna antosianin ekstrak etanol tepung kakao tanpa fermentasi terhadap kulit dapat dilihat pada Tabel 5. 
Tabel 5. Hasil Uji Iritasi Zat Warna Antosianin Ekstrak Etanol Tepung Kakao Tanpa Fermentasi

\begin{tabular}{|c|c|c|c|c|c|c|c|c|c|c|c|c|c|c|}
\hline & & \multirow{2}{*}{\multicolumn{4}{|c|}{ Kelinci 1}} & \multirow{2}{*}{\multicolumn{4}{|c|}{ Kelinci 2}} & \multirow{2}{*}{\multicolumn{4}{|c|}{ Kelinci 3}} & \\
\hline \multirow[t]{2}{*}{ Sampel } & Periode & & & & & & & & & & & & & \multirow[t]{2}{*}{ IIIKP } \\
\hline & $\begin{array}{c}\text { pengamatan } \\
\text { (jam) }\end{array}$ & \multicolumn{2}{|c|}{ Kiri } & \multicolumn{2}{|c|}{ Kanan } & \multicolumn{2}{|c|}{ Kiri } & \multicolumn{2}{|c|}{ Kanan } & \multicolumn{2}{|c|}{ Kiri } & \multicolumn{2}{|c|}{ Kanan } & \\
\hline & 0 & 0 & 0 & 0 & 0 & 0 & 0 & 0 & 0 & 0 & 0 & 0 & 0 & \multirow{4}{*}{0} \\
\hline \multirow[t]{3}{*}{ AS2 } & 24 & 0 & 0 & 0 & 0 & 0 & 0 & 0 & 0 & 0 & 0 & 0 & 0 & \\
\hline & 48 & 0 & 0 & 0 & 0 & 0 & 0 & 0 & 0 & 0 & 0 & 0 & 0 & \\
\hline & 72 & 0 & 0 & 0 & 0 & 0 & 0 & 0 & 0 & 0 & 0 & 0 & 0 & \\
\hline
\end{tabular}

Hasil uji iritasi zat warna antosianin dari ekstrak etanol tepung kakao tanpa fermentasi terhadap mata menggunakan sampel uji AS2 karena sampel ini memiliki warna yang lebih stabil. Hasil uji zat warna antosianin ekstrak etanol tepung kakao tanpa fermentasi terhadap mata dapat dilihat pada Tabel 6 .

Tabel 6. Hasil Uji Iritasi Zat Warna Antosianin dari Tepung Kakao Tanpa Fermentasi terhadap Mata.

\begin{tabular}{|c|c|c|c|c|c|c|c|c|}
\hline \multirow{3}{*}{ Sampel } & \multirow{3}{*}{$\begin{array}{c}\text { Periode } \\
\text { pengamatan }\end{array}$} & \multirow{2}{*}{\multicolumn{2}{|c|}{ Kornea }} & \multirow{3}{*}{ Iris } & \multirow{2}{*}{\multicolumn{3}{|c|}{ Konjunctiva }} & \multirow{3}{*}{ Keterangan } \\
\hline & & & & & & & & \\
\hline & & Opasitas & $\begin{array}{l}\text { Luas } \\
\text { opa }\end{array}$ & & Eritema & Khemosis & Lakrimasi & \\
\hline \multirow{5}{*}{ AS2 } & T0 & 0 & 0 & + & 0 & 0 & 0 & $\begin{array}{l}\text { Vokalisasi, } \\
\text { Berontak, } \\
\text { lakrimasi, } \\
\text { dan mata } \\
\text { keruh }\end{array}$ \\
\hline & T24 & 2 & 2 & - & 2 & 3 & 4 & $\begin{array}{l}\text { Kelopak } \\
\text { mata terbalik }\end{array}$ \\
\hline & T48 & 2 & 2 & - & 2 & 2 & 3 & $\begin{array}{l}\text { Kelopak } \\
\text { mata terbalik }\end{array}$ \\
\hline & T72 & 2 & 2 & - & 2 & 2 & 2 & $\begin{array}{l}\text { Kelopak } \\
\text { mata terbalik }\end{array}$ \\
\hline & T96 & 2 & 1 & - & 1 & 1 & 1 & $\begin{array}{l}\text { Kelopak } \\
\text { mata terbalik }\end{array}$ \\
\hline
\end{tabular}

Berdasarkan hasil uji zat warna antosianin dari tepung kakao tanpa fermentasi yang diekstrak menggunakan etanol dengan penambahan asam sitrat terhadap kulit (Tabel 5) menunjukkan bahwa zat warna antosianin dengan nilai pH 2,89 (Tabel 2) tidak bersifat toksik pada kulit atau tidak bersifat mengiritasi kulit dimana indeks iritasi kutan primer adalah nol. Ini menunjukkan bahwa penambahan asam sitrat pada ekstraksi senyawa antosianin tidak memberikan efek atau pengaruh nyata terhadap timbulnya iritasi pada kulit, karena asam sitrat tergolong kedalam asam-asam lemah dan nilai $\mathrm{pH}$ ekstrak antosianin dari biji kakao non fermentasi masih ditoleransi nilai pH kulit (Yumas, 2016).
Sedangkan uji iritasi pada mata (Tabel 6) menunjukkan bahwa zat warna antosianin dari ekstrak etanol tepung kakao tanpa fermentasi dengan penambahan asam sitrat terjadi iritasi pada wilayah iris mata hewan uji (kelinci) dimana kondisi kelopak mata hewan uji tersebut mengalami iritasi berat yaitu kelopak mata hewan uji terbalik. Walaupun asam sitrat tergolong ke dalam asam-asam lemah sebagai bahan tambahan pada proses ekstraksi zat warna antosianin, namun $\mathrm{pH}$ antosianin hasil ekstrak bersifat asam $\mathrm{pH} 2,89$ (Tabel 1) akibatnya antosianin memberikan efek iritasi yang nyata terhadap mata pada hewan uji (kelinci) dan bersifat sangat toksik pada mata. 


\section{SIMPULAN}

Serapan maksimum antosianin terjadi pada panjang gelombang $565 \mathrm{~nm}$ dengan nilai serapan antosianin tertinggi terjadi pada sampel AS2. Kestabilan zat warna antosianin dipengaruhi oleh suhu dan $\mathrm{pH}$ dimana semakin tinggi suhu, warna antosianin semakin tidak stabil sedangkan semakin rendah nilai $\mathrm{pH}$ atau bersifat asam, zat warna antosianin semakin stabil. Zat warna antosianin pada biji kakao non fermentasi yang terbaik adalah zat warna antosianin sampel AS2. Zat warna antosianin dengan $\mathrm{pH}$ 2,89 memiliki panjang gelombang maksimum $565 \mathrm{~nm}$ dengan serapan antosianin yang tertinggi sebesar 0,412, memiliki warnah merah kecoklatan yang stabil dan memiliki efek sebagai antioksidan, tidak bersifat toksik atau iritasi pada kulit, namun bersifat toksik atau iritasi pada mata. Zat warna antosianin dari tepung kakao tanpa fermentasi berpotensi sebagai zat warna alami pada produk pangan dan kosmetik serta berfungsi sebagai antioksidan.

\section{DAFTAR PUSTAKA}

1. Arivani, S. 2010. Total Antosianin Ekstrak Buah Salam dan Korelasinya dengan Kapasitas Anti Peroksidasi pada Sistem Linoleat. Agrointek, 4 (2) : 121127

2. Burduli D, Sarkinas A, Jasutiene I, Stackevicene E, Nikolajevas L, Janulis V.2009. Comparative Study of Anthocyanin Composition, Antimicrobial and Antioxidant Activity in Bilberry (Vaccinium myrtillus L) and Blueberry (Vaccinium corymbosum L) Fruids. Acta Pol Pharm 66:399-408

3. Choi JH, Hwang YP, Choi CY, Chung YC, Jeong HG, 2010. Anti-Fibrotic Effects of The Anthocyanins Isolated From The Purple-Fleshed Sweet Potato on Hepatic Fibrosis Induced By Dimethylnitrosamine Administration in Rats. Food Chem Toxicol 48: 31373143. DOI: 10.1016/j.fct.2010.08.009
4. Fathinatullabibah, Kawiji, Khasanah, L.U. 2014. Stabilitas Antosianin Ekstrak Daun Jati (Tectona grandis) terhadap Perlakuan pH dan Suhu. Jurnal Aplikasi Teknologi Pangan 3 (2) 2014 (C) Indonesian Food Technologists. Hal:6063

5. Hidayah, T., Pratjojo, W., dan Widiarti, N. 2014. Uji Stabilitas Pigmen Dan Antioksidan Ekstrak Zat Warna Alami Kulit Buah Naga. Indonesian Journal of Chemical Science 3 (2) 2014.

6. Ivo, M.I, Nur, N.M, Inderiyeni. 2017. Metode Uji Stabilitas, Iritasi, Dan Efek Antioksidan. Laporan Hasil Uji. Fakultas Farmasi ITB. PT. Lapi ganeshatama Consulting.

7. Jensen M B, Bergamo CA, Payet RM, Liu X, Konczak I, 2011. Influence of Copigment Derived from Tasmannia Pepper Leaf onDavidson's Plum Anthocyanins. J Food Sci 76: C447C453. DOI: $10.1111 / \mathrm{j} .1750$ 3841.2011.02077

8. Jiao Y, Jiang Y, Zhai W, Yang Z. 2012. Studies on Antioxidant Capacity of Anthocyanin Extract From Purple Sweet Potato (Ipomoea batatas L). Afr J Biotechnol 11: 7046-7054. DOI: 10.5897/AJB 11.3859

9. Kusuma, Y.T.C., Suwarsono, $S$ dan Yuwanti, S. 2013. Pemanfaatan Biji Kakao Inferior Campuran Sebagai Sumber Antioksidan Dan Antibakteri. Berkala IImiah Pertanian Vol. 1 (2): 3337

10. Laleh, G.H.,I. 2006. The Effect of Light, Temperature, $\mathrm{pH}$ and Species on Stability of Anthocyanin Pigments in Four Berberis Species. Pakistan Journal of Nutrition 5 (1): 90-92, 2006

11. Lee, J., Durst, R. W., and Wrolstad, R. E. 2005, Determination of Total monomeric Anthocyanin Pigment Content of Fruit Juices, Beverages, Natural Colorants, and Wines by the $\mathrm{pH}$ Differential Method: Collaborative Study. Jurnal of AOAC International Vol. 88, No. 5, pp. 1269-1278.

12. Marco PH, Poppi RJ, Scarminio IS, Tauler R. 2011. Investigation of The $\mathrm{pH}$ Effect And UV Radiation on Kinetic 
Degradation of anthocyanin Mixtures Extracted From Hibiscus acetosella. Food Chem 125: 1020-1027. DOI: 10.1016/j.foodchem.2010.10.005

13. Marliana, E. 2012. Aktivitas Antioksidan Ekstrak Etanol Daun Andong (Cordyline fruticosa[L] A. Cheval). Mulawarman Scientifie, Volume 11, Nomor 1, April 2012

14. Moulana, R., Juanda., Rahaya, S., dan Rasika, R. 2012. Efektivitas Penggunaan Jenis Pelarut dan Asam Dalam Proses Ekstraksi Pigmen antosianin Kelopak Bunga Rosella (Hibiscus sabdariffa L). Jurnal Teknologi Pertanian Indonesia Vol (4) No. 32012. Hal:20-25.

15. Molyneux, P. 2004. The Use of the Stable Free Radical Diphenylpicrylhydrazyl (DPPH) for Estimating Antioxidant Activity. Songklanakarin Journal of Science and Technology. 26, 211-219.

16. Reyes LF, Cisneros-Zevallos L. 2007. Degradation Kinetics And Colour of Anthocyanin in Aqueous Extracts of Purple And Red-Flesh Potatoes (Solanum tuberosum L). Food Chem 100: 885-894.

DOI:

10.1016/j.foodchem.2005.11.002

17. Sancho RAS, Pastore GM. 2012. Evaluation of The Effects of Anthocyanins in Type 2 Diabetes. Food Res Int 46: 378-386. DOI: 10.1016/j.foodres.2011.11.021

18. Sari dan Puspita,. 2005. Ekstraksi dan Stabilitas Antosianin dari Kulit Buah Duwet (Syzgium cumini). Jurnal Teknologi dan Industri Pangan Vol.XVI No.2 Tahun 2005.

19. Suda, I., Oki, T., Masuda, M., Kobayashi, M., Nishiba, Y. Dan Furuta, S. (2003). Review: Physiological functionality of purple-fleshed seet potatoes containing anthocyanins and their utilization in foods. Japan Agricultural Research Quarterly 37: 167173.

20. Takahata Y, Kai Y, Tanaka M, Nakayama H, Yoshinaga M. 2011. Enlargement of The Variances in Amount and Composition of
Anthocyanin Pigments in Sweetpotato Storage Roots and Their Effect on The Differences in DPPH Radical-Scaveging Activity. Hortic-Amsterdam 127: 469474. DOI: 10.1016/j.scienta.2010.10.010

21. Tensiska,. 2003. Aktivitas Antioksidan Ekstrak Buah Andaliman (Zanthoxylum Acanthopodium DC) Dalam Beberapa Sistem Pangan Dan Kestabilan Aktivitasnya Terhadap Kondisi Suhu dan $\mathrm{pH}$. Jurnal teknologi dan industri pangan. Vol. xiv No. 1 Tahun 2003

22. Torskangerpoll K, Andersen OM. 2005. Colour Stability of Anthocyanins in Queous Solutions at Various pH Values. Food Chem 89:427-440. DOI: 10.1016/j.foodchem.2004.03.02

23. Wang, Chau-jong. 2008. Hibiscus Anthocyanins for Inhibiting Cancers. United States Paten 20080113050

24. Wulaningrum, R.A., Sunarto, W., Alauhdin, M. 2013. Pengaruh Asam Organik Dalam Ekstrak Zat Warna Kulit Buah Manggis (Garcinia magostana). Indonesian Journal of Chemical Science 2 (2) ISSN No. 2252-6951.

25. Wrolstad, R. E., Durst, R.W, and Lee, J. 2005. Tracking Color and Pigment Changes In Anthocyanin Products. Elsevier 16: 423-428.

26. Yumas, M. 2017. Pemanfaatan Limbah Kulit Ari Biji Kakao (Theobroma cacao L) Sebagai Sumber Antibakteri Streptococcus mutans. Jurnal Industri Hasil Perkebunan Vol. 12 No. 2 Desember 2017 e-ISSN 2477-0051 Akreditasi LIPI No. 725/AU3/P2MILIPI/04/2016. Hal: 7-20

27. Yumas, M. 2016. Formulasi Sediaan Krim Wajah Berbahan Aktif Ekstrak Metanol Biji Kakao Fermentasi (Theobroma cacao L) Kombinasi Madu Lebah. Jurnal Industri Hasil Perkebunan Vol. 11 No. 2 Desember 2016 e-ISSN 2477-0051 Akreditasi LIPI No. 725/AU3/P2MI-LIPI/04/2016. Hal: 75-78. 